\title{
Emerging therapeutic agents for lung cancer
}

\author{
Bhagirathbhai Dholaria, William Hammond, Amanda Shreders and Yanyan Lou ${ }^{*}$
}

\begin{abstract}
Lung cancer continues to be the most common cause of cancer-related mortality worldwide. Recent advances in molecular diagnostics and immunotherapeutics have propelled the rapid development of novel treatment agents across all cancer subtypes, including lung cancer. Additionally, more pharmaceutical therapies for lung cancer have been approved by the US Food and Drug Administration in the last 5 years than in previous two decades. These drugs have ushered in a new era of lung cancer managements that have promising efficacy and safety and also provide treatment opportunities to patients who otherwise would have no conventional chemotherapy available. In this review, we summarize recent advances in lung cancer therapeutics with a specific focus on first in-human or early-phase I/II clinical trials. These drugs either offer better alternatives to drugs in their class or are a completely new class of drugs with novel mechanisms of action. We have divided our discussion into targeted agents, immunotherapies, and antibody drug conjugates for small cell lung cancer (SCLC) and non-small-cell lung cancer (NSCLC). We briefly review the emerging agents and ongoing clinical studies. We have attempted to provide the most current review on emerging therapeutic agents on horizon for lung cancer.
\end{abstract}

Keywords: Lung cancer, Targeted agents, Immunotherapy, Phase I/II clinical trial

\section{Background}

Lung cancer is the second most commonly diagnosed cancer and is the leading cause of cancer-related death in both men and women. Implementation of tobacco control, low-dose spiral computed tomography screening programs, and advances in multidisciplinary treatments have resulted in the slow decline of both incidence and mortality. However, $52-58 \%$ of lung cancer patients present with advanced-stage disease, and a vast majority of these patients do not survive despite treatment. Similarly, the prognosis remains poor even in locally advanced disease because of the high relapse rate and early formation of micrometastases [1].

One of the most important therapeutic advances of lung cancer treatment in the last decade was identification of specific driver mutations and the development of small molecular tyrosine kinase inhibitors (TKIs) [2]. In 2009, erlotinib was the first selective epidermal growth factor receptor (EGFR) inhibitor approved by the US Food and Drug Administration (FDA) [3]. This

\footnotetext{
* Correspondence: Lou.Yanyan@mayo.edu

Department of Hematology-Oncology, Mayo Clinic, 4500 San Pablo Road, Jacksonville, FL 32224, USA
}

(c) The Author(s). 2016 Open Access This article is distributed under the terms of the Creative Commons Attribution 4.0 International License (http://creativecommons.org/licenses/by/4.0/), which permits unrestricted use, distribution, and reproduction in any medium, provided you give appropriate credit to the original author(s) and the source, provide a link to the Creative Commons license, and indicate if changes were made. The Creative Commons Public Domain Dedication waiver (http://creativecommons.org/publicdomain/zero/1.0/) applies to the data made available in this article, unless otherwise stated.

was quickly followed by crizotinib, which was initially developed as a MET (mesenchymal-to-epithelial transition/hepatocyte growth factor receptor) inhibitor and was found to be highly active against small subset of non-small-cell lung cancer (NSCLC) cases harboring anaplastic lymphoma kinase (ALK) rearrangement [4]. These drugs promise around a $70 \%$ response rate; however, resistance development is almost universal, and second/third generation TKIs are being developed to overcome these issues. Novel targeted agents directed against EGFR, ALK, ROS1, MET, RET, BRAF, and many more are under investigation. Figure 1 provides summary of targets with specific focus on the drugs that currently in early-phase clinical trials in lung cancer. In addition to these drugs, next-generation sequencing and cell-free DNA (cfDNA) technologies have provided rapid and convenient tools for gene abnormality testing and the development of targeted therapies [5]. Additionally, personalized medicine has become part of daily practice, and tailoring treatment for individual patients is becoming a reality.

Immunotherapy in the form of checkpoint inhibitors represents a landmark success in NSCLC treatment, and 


\section{TARGETED THERAPY}

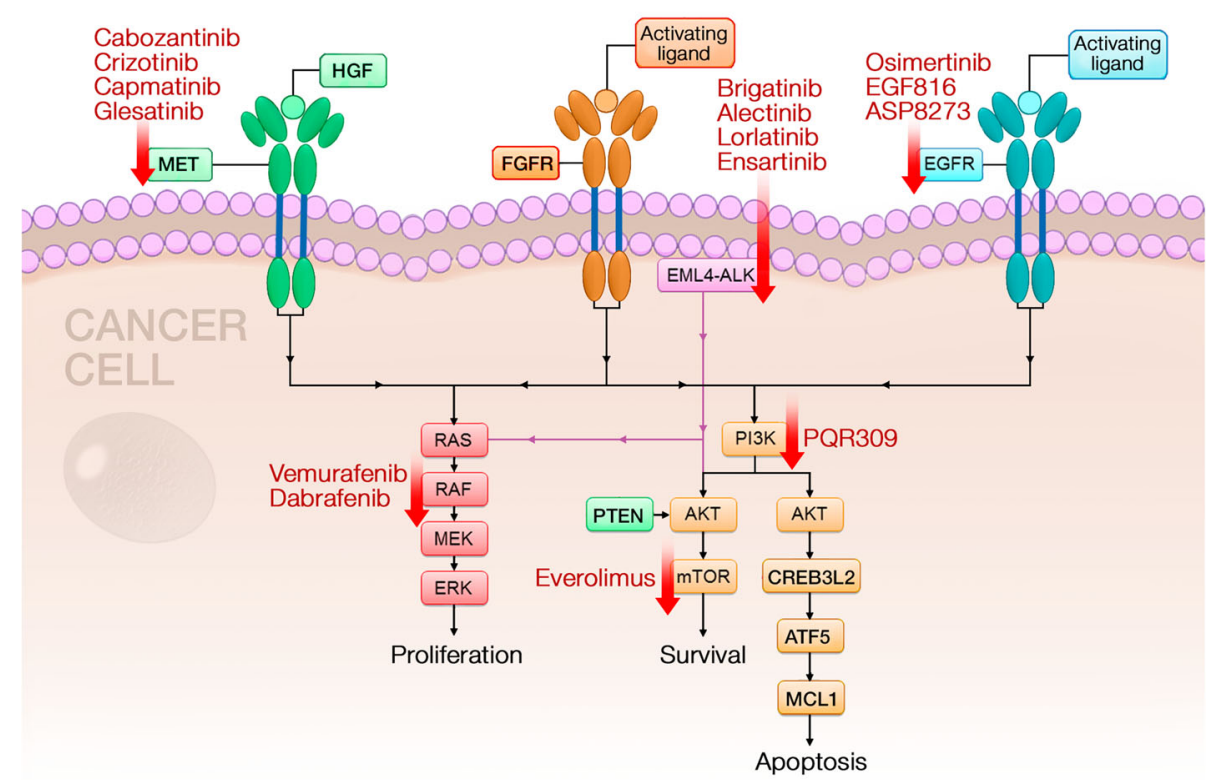

Fig. 1 Molecular targets and inhibiting agents being studied in phase I/II trials as potential therapy for patients with lung cancer. Abbreviations: AKT protein kinase B, ALK anaplastic lymphoma kinase, CREB3L2 cyclic AMP-responsive element-binding protein 3-like protein 2, EGFR epidermal growth factor receptor, EML4 echinoderm microtubule-associated protein-like 4, ERK extracellular signal-regulated kinase, FGFR fibroblast growth factor receptor, HGF hepatocyte growth factor, MCL1 myeloid leukemia cell differentiation protein, MEK mitogen-activated protein kinase, MET mesenchymal-to-epithelial transition, MTOR mammalian target of rapamycin, PTEN phosphatase and tensin homologue, RAF rapidly accelerated fibrosarcoma kinase, $R E T$ rearranged during transfection proto-oncogene

patients have experienced durable responses with good tolerability. Pembrolizumab and nivolumab exert antitumor activity by blocking programmed death receptor-1 (PD-1) on $\mathrm{T}$ lymphocytes. These drugs are currently approved as second-line therapies for advanced NSCLC based on pilot studies that show improved and durable responses compared to docetaxel [6-8]. Most recently, the FDA approved pembrolizumab for the treatment of patients with metastatic NSCLC whose tumors express strong PD-L1 in the first-line setting based on significant improvement in progression-free survival (PFS) and overall survival (OS) [9]. Trials are underway to test using these agents as first-line therapies for patients with NSCLC either alone or in combination with chemotherapy, TKIs, radiation, and other immunotherapies [9-12]. For example, combinations of CTLA-4 and PD-1 inhibitors have been investigated in patients with NSCLC and small cell lung cancer (SCLC). Preliminary results from a phase I study demonstrated that ipilimumab and nivolumab can be effectively and safely combined as first-line treatment of advanced NSCLC [10]. This combination is currently being tested in ongoing phase III study. Similarly, increased antitumor activity was also seen in SCLC with this combination [11]. Multiple studies are underway to investigate the clinical activities of combined chemotherapy and checkpoint inhibitors. Studies to investigate the roles of checkpoint inhibitors in adjuvant and neoadjuvant settings in early-stage lung cancers are ongoing as well. These exciting developments have fuelled rapid progress in the field, and multiple molecules targeting different aspects of host-tumor immune interactions are currently being investigated. Figure 2 provides the summary of ongoing strategies and efforts in immunotherapy of lung cancer.

In this review, we have discussed recently published data on the first-in-human clinical trials and some of the most promising drugs in pipeline. Literature was searched for phase $1 / 2$, first in human clinical trials in lung cancer by using PubMed, Google scholar, and the American Society of Clinical Oncology (ASCO) meeting abstracts. Each study was individually reviewed and data points have been summarized.

\section{Targeted agents EGFR inhibitors}

EGFR is a member of the ErbB tyrosine kinase receptor (TKR) family and is referred to as ErbB1 or HER1. Gefitinib was first tested for EGFR-expressing NSCLC. It targets the ATP cleft within EGFR, which is 


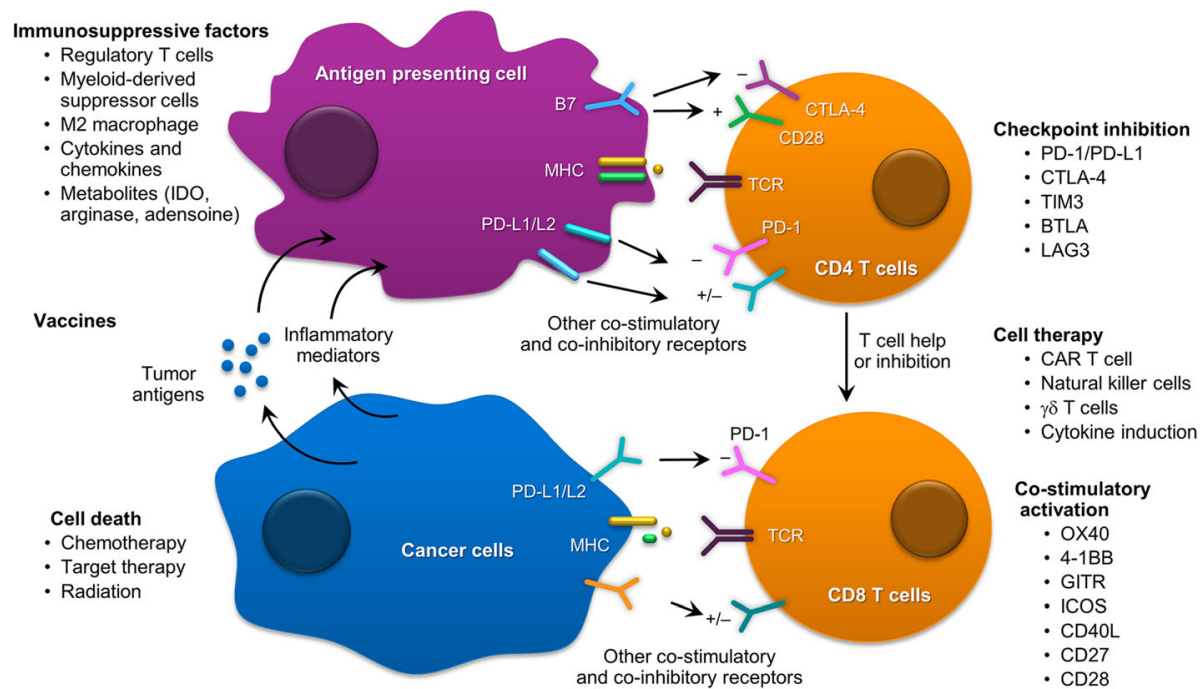

Fig. 2 Multifaceted immunotherapy approaches to target cancer cell

overexpressed in $40-80 \%$ of NSCLC cases. Later, Lynch et al. demonstrated that only the tumors with somatic mutations in tyrosine kinase domain of the EGFR gene responded to gefitinib [13]. Testing for driver mutations in newly diagnosed, advanced NSCLC cases has become the standard of care. In patients who carry the targetable driver mutation, a first-line treatment with targeted agents is recommended over conventional chemotherapy. These drugs are well tolerated and give predictable objective response. A phase 2 trial in neo-adjuvant settings has shown an improved response rate compared to chemotherapy in EGFR+ NSCLC [14]. Driver mutations in EGFR (exon 19 deletion or exon 21 L858R substitution) are found in $15-20 \%$ of all lung adenocarcinomas (ACs) that account for the largest group of lung cancer patients. Erlotinib, gefitinib, and afatinib are approved as first-line treatments for targetable EGFR alterations. The median progression-free survival (PFS) from these agents is 9.2-13.1 months [15-17]. Dacomitinib is a small molecule, irreversible inhibitor active against all HER family of tyrosine kinases. In randomized trials, it has comparable efficacy to erlotinib. The subgroup with EGFR exon 19 deletion has better PFS with dacomitinib compare to erlotinib (HR $0.585, P=0.058$ ) $[18,19]$. A recent phase 3 trial (NCT01040780) comparing icotinib with gefitinib as the first-line EGFR TKI treatment showed similar results in Chinese patients [20].

\section{T790M mutant-selective EGFR TKIs}

After the initial response to EGFR TKI, resistance development through various mechanisms is inevitable. The EGFR T790M mutation causes acquired resistance to the first- and second-generation TKIs. T790M mutationselective third-generation EGFR TKIs (osimertinib, rociletinib) have been developed with encouraging overall response rates up to $60 \%$ [21, 22]. Osimertinib was approved in 2015 by the FDA for confirmed EGFR T790M mutation-positive NSCLC. A first-line trial (NCT02296125) is underway to compare osimertinib vs erlotinib or gefitinib. This should give information on ideal sequencing on these agents. ASP8273 and olmutinib (BI1482694) are other third-generation T790M-selective EGFR TKIs. Early-phase studies (NCT02113813, NCT01588145) in T790M-positive NSCLC showed an overall response rate (ORR) of 31\% and disease control rate (DCR) of $57 \%$ for ASP8273, as well as a $61 \%$ ORR and 90\% DCR for BI1482694. The median PFS was 6.8 and 8.3 months, respectively [23, 24]. EGF816 is another agent that showed an ORR of $44 \%$ and DCR of 91\% in a phase 1 study (NCT02108964) [25]. Typical EGFR TKI-related adverse events were observed with all three drugs.

\section{CNS-penetrant EGFR TKIs}

Central nervous system (CNS) metastasis is a common site of disease progression in EGFR+ NSCLC, leading to failure of the first-line TKIs. AZD3759 is a potent CNS-penetrant EGFR TKI currently being evaluated along with osimertinib in a phase 1 (BLOOM) study (NCT02228369) in patients with progressive CNS metastasis who have already had first-line treatment with EGFR TKI. AZD3759 showed activity in 20 patients with measurable brain metastasis evaluable for RECIST assessment; 8 had tumor shrinkage in the brain, 3 had confirmed partial response (PR), and 3 had unconfirmed PR [26]. In 12 patients taking osimertinib, 7 had radiological PR, 2 had stable disease, and 3 were not evaluable after 12 weeks [27]. 
Epitinib is another small-molecule TKI being developed for its favorable CNS penetration. In a doseexpansion phase, 12 patients with EGFR+ NSCLC and CNS metastasis received epitinib. Among those 12 evaluable patients, 5 reached PR (all treatment naïve) and showed dramatic shrinkage of brain lesions. The five prior-TKI-treated patients had stable disease (SD) in the brain [28] (NCT02590952).

\section{ALK inhibitors}

$A L K$ fusion oncogene-associated NSCLC is a distinct subset of lung cancer amenable to targeted therapy. $A L K$ rearrangement is found in $3-13 \%$ of NSCLC cases, with a higher prevalence among younger patients, never or light smokers, and adenocarcinoma with signet ring or acinar histology [29]. Crizotinib is a multi-targeted TKI that is active against $A L K, R O S 1$, and MET [4]. It has been approved as a first-line treatment for $A L K+$ or ROS1+ NSCLC. Ceritinib and alectinib are secondgeneration ALK TKIs approved for crizotinib-resistant or intolerant cases [30-32]. Resistance development and CNS progression are major issues, and the following ALK TKIs are currently under investigation.

Brigatinib was given to 222 patients with crizotinibrefractory, $A L K+$ NSCLC under a phase II study (ALTA, NCT02094573). A PFS of 8.8 and 11.1 months was noted among those receiving lower and higher doses of brigatinib, respectively. An encouraging intracranial ORR of $67 \%$ was seen in nine patients with measurable CNS metastasis. Early onset pulmonary toxicity was seen in 6\% of the patients [33]. A phase III trial (NCT02737501) against crizotinib in a front-line setting for $A L K+$ NSCLC has been initiated.

Lorlatinib (PF-06463922) was tested in phase I/II study (NCT01970865) of $A L K+/ R O S+$ NSCLC. A majority of the participants had a prior treatment with $\geq 2$ ALK TKIs. Among 41 evaluable patients, an ORR 46\% and median PFS of 11.4 months were seen. The intracranial ORR was $44 \%$, including a few complete responses (CRs) [34]. Interestingly, the drug was active against diseases caused by the $A L K$ G1202R mutation which confers resistance to ceritinib, alectinib, and brigatinib [35].

Ensartinib (X-396) is a novel ALK inhibitor with additional activity against ROS1, MET, SLK, Axl, LTK, ABL, and EPHA2. Partial responses were seen in $60 \%$ crizotinib-naïve (30 patients) and $88 \%$ crizotinib-resistant patients (12 patients) (NCT01625234). CNS responses were also observed in both groups [36]. A phase 3 study (NCT02767804) comparing ensartinib and crizotinib in a front-line setting is currently recruiting patients.

\section{MET inhibitors}

MET, a receptor tyrosine kinase after binding with hepatocyte growth factor (HGF), activates the phosphatidylinositol-3-kinase (PI3K) and mitogenactivated protein kinases (MAPK) pathways. MET gene amplification and exon-14-skipping mutations are characteristic abnormalities causing increased MET signaling activation. Isolated $M E T$ exon 14 mutation is found in 3\% of NSCLC; however, it is an acquired EGFR TKI resistance pathway in 15-20\% of EGFR mutation-positive NSCLC cases [37, 38]. Crizotinib has shown some activity in selected $M E T$-amplified and exon 14-skipping mutant NSCLC [39, 40] (NCT00585195). Cabozantinib, a multi-targeted MET inhibitor, was given to five patients with exon 14 mutations and had a stable disease for 5 months [40]. Capmatinib (INC280) is a selective MET inhibitor. In a phase I study (NCT01324479), relapsed NSCLC patients with high cMET expression were given capmatinib. In subgroup of patients with $M E T$-amplified disease, the ORR was $63 \%$, and the median PFS was 7.4 months [41]. Glesatinib (MGCD265) is another MET blocker currently being studied in NSCLC (NCT00697632).

\section{Combined MET + EGFR inhibitors}

Acquired EGFR TKI resistance is mediated by MET upregulation in a subset of NSCLC patients. One strategy to overcome this resistance is to combine a MET inhibitor with an EGFR TKI. A combination of capmatinib and gefitinib was tested in a phase 2 study (NCT01610336) in EGFR+ NSCLC patients after their disease progressed while using gefitinib. EGFR T790M NSCLCs were excluded and high cMET expression was required. An ORR of $18 \%$, an SD of $62 \%$, and a DCR of $80 \%$ were observed in 65 evaluable patients. More responses were seen in tumors with $M E T$ amplifications [42]. Tepotinib (MSC2156119J) with gefitinib was well tolerated in a phase 1 study (NCT01982955). Eighteen patients were treated, and five had a partial response [43]. A similar trial (NCT01900652) with emibetuzumab and an IgG4 anti-MET monoclonal antibody $(\mathrm{mAb})$ with erlotinib in MET-expressing NSCLC with acquired erlotinib resistance showed some benefit in high cMET-expressing tumors [44].

\section{RET inhibitors}

The RET proto-oncogene encodes a receptor tyrosine kinase for members of the glial cell line-derived neurotrophic factor (GDNF) family. RET rearrangements are found in 1-2\% lung adenocarcinoma and are mutually exclusive with mutations involving EGFR, $A L K$, or $K R A S$. Vandetanib, sorafenib, sunitinib, lenvatinib, ponatinib, and cabozantinib are multi-targeted TKIs with RET-blocking activity. They are currently approved for other malignancies. In a phase 2 study with cabozantinib, 38\% PR was seen among 16 evaluable patients, and there was a median PFS of 7 months [45]. 
Vandetanib in advanced RET-rearranged NSCLC showed an ORR 53\%, a DCR 88\%, and a median PFS of 4.7 months in 17 eligible patients. The CCDC6-RET subtype had an ORR of $83 \%$ and a median PFS of 8.3 months [46] (UMIN000010095). In a phase 1 study (NCT01582191), vandetanib was combined with everolimus (mTOR (mammalian target of rapamycin) inhibitor) to prevent resistance development based on in vitro studies. Among 13 stage IV NSCLC patients, PR was achieved in five patients with RET fusion. Good CNS activity was seen in three patients with intracranial metastasis [47].

\section{BRAF/MEK inhibitors}

BRAF is a downstream signaling mediator of KRAS, which activates the MAP kinase pathway. BRAF mutations are found in $1-2 \%$ of NSCLC cases and are usually smoking related [48]. It is also described as one of the resistance mechanisms associated with EGFR TKIs. Vemurafenib and dabrafenib are currently approved for $B R A F$ V600E-positive malignant melanomas, but singleagent activity in BRAF V600E- positive NSCLC is limited. Dabrafenib had an ORR of $33 \%$ in platinum refractory cases with a median duration of response of 9.6 months in single study [49] (NCT01336634).

\section{Combination BRAF + MEK inhibitors}

Sequential inhibition of BRAF and downstream MEK is an active area of lung cancer research after encouraging results were seen in melanoma patients. Dabrafenib with trametinib (MEK inhibitor) was associated with ORR of $63 \%$ in 57 evaluable patients and the DCR was $79 \%[50]$.

\section{Combination MEK inhibitor and immunotherapy}

MEK inhibition can result intratumoral $\mathrm{T}$ cell accumulation and MHC-1 upregulation and synergizes with anti-PD-L1 agent leading to tumor regression [51]. Cobimetinib is a selective MEK1 and MEK2 inhibitor. In a phase 1b study (NCT01988896), cobimetinib with atezolizumab (anti-PD-L1) was given to advanced solid cancer patients. In colorectal cancer cohort (MSI-low), ORR was $17 \%$ and responses were durable. Increased PD-L1 and CD8 T lymphocyte infiltration was demonstrated in serial biopsies [52]. Results on NSCLC cohort are pending.

\section{PI3K inhibitors}

Phosphatidyl 3-kinase (PI3K) pathway is a central mediator of cell survival signals. PI3CA mutations are found in $4.4 \%$ of lung adenocarcinoma and $16 \%$ of squamous cell cancer. PI3CA amplifications are found in up to $40 \%$ of squamous cell lung cancer [53,54]. PI3CA mutations also promote resistance to EGFR TKIs. PQR309 is a
pan-PI3K, mTOR inhibitor. Its safety and maximum tolerated dose have been recently established in a phase 1 study (NCT02483858) with advance solid cancers. No response data are available for NSCLC cohort [55].

\section{HER3 inhibitors}

Patritumab is a fully human anti-HER3 mAb. HER3 is a member of the ErbB tyrosine kinase receptor family and is activated by heregulin. Preclinical studies with EGFR+ NSCLC cell lines have shown that increased heregulin level confers resistance to EGFR TKI. An initial phase 2 study (NCT01211483) failed to show the PFS benefit of adding patritumab to erlotinib compared to a placebo. However, the subgroup with increased soluble heregulin showed increased PFS (HR 0.41 [95\% CI 0.18-0.90], $P=$ 0.02 ) with patritumab [56]. A phase 3 placebo-controlled study (HER3-Lung, NCT02134015) in EGFR+ NSCLC is ongoing.

\section{Aurora A kinase inhibitors}

Aurora A is a member of a family of mitotic serine/ threonine kinases which assist with cell proliferation. Alisertib (MLN-8237) is an aurora kinase A inhibitor. Based on in vitro synergism with EGFR TKIs, it was tested in 18 patients with EGFR+ NSCLC. The combination was well tolerated; one patient had a PR, while five other patients achieved SD [57]. Phase 2 recruitment is ongoing (NCT01471964).

\section{FGFR inhibitors}

The fibroblast growth factor receptor (FGFR) binds to members of the fibroblast growth factor family of proteins and promotes cell proliferation. BGJ398 is a potent, selective pan-FGFR (fibroblast growth factor receptor). FGFR1 amplification is found in around $21 \%$ of squamous NSCLC cases [58]. In a single phase 2 trial, 26 evaluable patients showed a PR of $15 \%$ and an SD if $35 \%$ in dose $>100 \mathrm{mg}$ [59]. Dovitinib is another FGFR inhibitor tested in squamous NSCLC. Among 26 patients, the ORR was $11.5 \%$, the DCR was $50 \%$, and the median PFS was 2.9 months [60].

\section{PARP inhibitors}

PARP (poly ADP ribose polymerase) plays an important role in DNA repair. PARP inhibitors have synergistic activity with platinum based chemotherapy (i.e., cisplatin) [61]. In a phase 2 study, veliparib in combination with carboplatin and paclitaxel was tested in first-line setting for advanced NSCLC. The combination was well tolerated, and there was a trend toward favorable PFS (HR 0.72 [95\% CI $0.45-1.15, P=0.17]$ ) and OS (HR 0.80 [95\% CI 0.54-1.18, $P=0.27]$ ) in combination arm [62]. A phase 2 combining veliparib with chemoradiation in stage 3 NSCLC is recruiting (NCT02412371). 


\section{Immunotherapies}

Immunotherapy has long been considered the holy grail of Oncology. Different attempts have been made to harness body's immune system to eradicate malignancy. Lung cancer has the second highest mutation burden after melanoma, which increases its susceptibility to immunotherapy [63]. One of the key advantages of immunotherapy is the durability of responses. Where resistance development is universal with chemotherapy and targeted agents, memory function of the immune system can lead to lasting remission. Check point inhibitors target the PD1/PD-L1 axis to remove the inhibitory signals on $\mathrm{T}$ lymphocytes to eradicate malignancy. Pembrolizumab and nivolumab are currently approved as second-line therapies for both adenocarcinoma and squamous cell carcinoma of lung. Atezolizumab is the first anti-PD-L1 agent approved by the FDA for NSCLC in second-line setting after encouraging results from phase 3 OAK trial showing superior OS.(HR 0.73; $P=$ 0.0003) [64]. A recent phase 3 study tested pembrolizumab vs platinum doublet chemotherapy in first-line NSCLC with at least 50\% PD-L1expression in tumor cells. Pembrolizumab was associated with better PFS (10.3 vs 6 months) and response rate (44.8 vs 27.8\%) compared to chemotherapy. Estimated survival at 6 months was also better in patients treated with pembrolizumab ( $\mathrm{HR}=0.60, P=0.005)$ [9]. This had led to approval of pembrolizumab as first-line therapy in NSCLC with $>50 \%$ PD-L1 expression in tumor cells. A combination of ipilimumab and nivolumab as first-line treatment in advanced NSCLC is feasible, safe, and has shown good ORR [10]. Durvalumab (anti-PD-L1) and tremelimumab (anti-CTLA4) have been tested in phase $1 \mathrm{~b}$ study and found to be safe with early evidence of clinical activity in relapsed NSCLC [65]. As these agents move quickly to treat early-stage lung cancers through clinical studies, other agents that target different aspects of the tumor-immune system milieu are being developed. Figure 2 demonstrates different strategies being utilized to enhance tumor recognition and elimination by the immune system [66].

\section{OX40}

OX40 (CD134) is a secondary costimulatory immune checkpoint receptor expressed on activated $\mathrm{T}$ cells that lead to expansion of effector and memory $\mathrm{T}$ cells after binding with OX40L (CD252) on antigen presenting cells. It is a part of tumor necrosis factor receptor (TNFR) superfamily and works in conjunction with B7 family members, such as PD1 and CTLA-4. GSK3174998 is a humanized IgG1 agonistic anti-OX40 monoclonal antibody $(\mathrm{mAb})$ that promotes naïve $\mathrm{CD} 4+\mathrm{T}$ - cells and suppresses their differentiation into immunosuppressive regulatory $\mathrm{T}$ cells $\left(\mathrm{T}_{\text {reg }}\right)[67,68]$. ENGAGE-1
(NCT02528357) is a first-in-human study of GSK3174998 alone and in combination of pembrolizumab. Murine studies have shown synergistic activity between PD-1 blockade and OX40 agonist mAb [69]. No doselimiting toxicity was found in the initial dose escalation cohort alone and in combination with a 200-mg fixed dose of pembrolizumab every 3 weeks. This study is still recruiting patients.

MEDI6383 (NCT02221960) is another OX40 agonist $\mathrm{mAb}$ currently being studied with durvalumab, an antiPD-1 antibody. Lirilumab/BMS-986015 (NCT01714739) is anti-KIR mAb, which is a natural killer (NK)-cell checkpoint inhibitor that is being evaluated with nivolumab.

\section{Lymphocyte activation gene 3}

Lymphocyte activation gene 3 (LAG-3, CD223) is another checkpoint inhibitor on activated $\mathrm{T}$ lymphocytes that inhibits immune function after binding with major histocompatibility complex (MHC) II [70]. Urelumab is an anti-LAG3 mAb currently being studied for NSCLC in combination with anti-PD1 agents (NCT01968109, NCT02460224).

\section{T cell immunoglobulin and mucin-domain containing-3}

$\mathrm{T}$ cell immunoglobulin and mucin-domain containing-3 (TIM-3) is Th1 (T helper-1)-specific regulator of macrophage responses. Recently, murine studies showed TIM3 upregulation in the tumor microenvironment in an anti-PD1 resistant NSCLC model [71]. MBG453 and TSR-022 are anti-TIM3 mAbs currently being studied in two phase 1 trials (NCT02817633, NCT02608268).

\section{B7-H3}

B7-H3 is widely expressed among tumors and is associated with immune escape and metastasis. MGD009 is a humanized B7-H3 and CD3 dual-affinity re-targeting (DART) protein designed to engage $\mathrm{T}$ cells to $\mathrm{B} 7-\mathrm{H} 3$ expressing cells. Antitumor activity in multiple in vivo models has been demonstrated. A phase 1 trial (NCT02628535) in advanced B7-H3 expressing tumors, including NSCLC, is recruiting patients [72]. Prior antiPD1 therapy is allowed.

\section{MUC1}

MUC1 is widely expressed in many malignancies, including NSCLC. TG4010 is a modified vaccinia Ankara expressing MUC1 and interleukin 2 (IL2). In a recent phase 2b study, TG4010 or placebo were given with chemotherapy as a first-line therapy for metastatic NSCLC (mNSCLC) without EFGR mutations and MUC1 expression in minimum $50 \%$ of tumor cells. Significant improvement in PFS (hazard ratio 0.74, 95\% CI 0.55$0.98, P=0.019)$ was noted. The phase 3 component is ongoing [73]. 


\section{GM.CD40L}

GM.CD40L is an allogeneic tumor cell vaccine developed from a human bystander cell line. Cells are transduced with granulocyte-macrophage colony-stimulating factor $(G M-C S F)$ and CD40-ligand (CD4OL) genes. In vivo, it stimulates dendritic cell-mediated immune response. CCL21 is a chemokine that helps with T cell responses. In a phase 1/2 study (NCT01433172), GM.CD40L + CCL21 did not improve PFS, and the median OS was comparable to single-agent chemotherapy in advanced adenoNSCLC. A combination study with anti-PD1 is underway [74].

\section{Antibody drug conjugates}

Antibody drug conjugates (ADCs) are an important class of biologics currently being investigated for range of malignancies. The chemotherapy molecule is attached to a target-specific antibody for tumor-directed cytotoxicity but sparing of normal tissue. Brentuximab vedotin (CD30 directed) and transtuzumab emtansine (HER2 directed) are ADCs currently available for relapsed Hodgkin lymphoma and metastatic HER2-positive breast cancer, respectively. The following ADCs are currently being studied in phase 1 trial for lung cancer.

\section{Sacituzumab govitecan (IMMU-132)}

Trop-2 is widely expressed among solid tumors. Sacituzumab govitecan is made from a humanized anti-Trop-2 monoclonal antibody (hRS7) that is conjugated with the active metabolite of irinotecan, SN-38. In a phase $1 / 2$ study (NCT01631552), the single-agent sacituzumab govitecan was given to patients with advanced epithelial malignancies. In the NSCLC cohort, an objective response of $31 \%$ and median PFS of 3.9 months was observed. The SCLC cohort showed a similar response rate, a median PFS of 4.6 months, and a median OS of 8.3 months $[75,76]$. Diarrhea and neutropenia were common adverse events. These are encouraging results in platinum refractory patients. It has received the FDA breakthrough therapy designation for triple-negative breast cancer.

\section{Rovalpituzumab tesirine (SC16LD6.5)}

Rovalpituzumab tesirine also known as Rova-T is an antibody (SC16) targeting delta-like protein 3 (DLL3) and is linked to pyrrolobenzodiazepine (PBD). DLL3, an inhibitory Notch ligand, is expressed in $>80 \%$ of SCLCs. The first biomarker directed trial for advanced SCLC showed an objective response rate of $18 \%$ and a clinical benefit rate of $68 \%$ as a second or third line of therapy in evaluable patients. Interestingly, 27 patients with high DLL3-tumor expression had a response rate of 44 and $45 \%$ in the second- and third-line settings, respectively [77]. Thrombocytopenia, a skin rash, and serosal effusions were dose-limiting toxicities. A phase 2 study
(TRINITY; NCT02674568) is recruiting patients with DLL3-expressing SCLC.

\section{Cancer stemness inhibitors}

Cancer stem cells are highly resistant to traditional therapies and cause disease relapse after initial response. Napabucasin (BBI608) is a first-in-class cancer stemness inhibitor that works through STAT3 pathway inhibition. It has shown activity in combination with paclitaxel. In a phase 2 study (NCT01325441), 27 heavily pretreated NSCLC patients were given a combination of napabucasin and weekly paclitaxel. Among 19 evaluable patients, there was a PR of $16 \%$, a DCR of $79 \%$, and a median PFS of 4 months [78].

Demcizumab (VS-6063) is a humanized IgG $_{2}$ anti-DLL4 (delta-like ligand 4) antibody that inhibits tumor growth by suppressing the Notch pathway. A phase 1b study (NCT01189968) tested demcizumab with carboplatin and pemetrexate as first-line therapies for lung adenocarcinoma. Results showed complete responses in one $(3 \%)$ of 40 patients and partial responses in 19 (47\%) patients [79]. A randomized, placebo-controlled phase 2 trial (DENALI) (NCT02259582) has opened for first-line non-squamous NSCLC. Another study (NCT01859741) of first-line chemotherapy for SCLC is still recruiting patients.

Tarextumab (OMP-59R5) is a human anti-Notch 2/3 receptor $\mathrm{mAb}$. In the phase $1 \mathrm{~b}$ portion of the PINNACLE study, tarextumab was given with etoposide/platinum chemotherapy in the first-line extensive stage SCLC. The combination was well tolerated. The RECIST response was $77 \%$ with a median PFS and OS of 4.4 and 10.4 months, respectively, in 27 treated patients [80]. A randomized study (NCT01859741) is ongoing.

\section{Future directions}

We discussed results of first-in-human phase I/II clinical trials with novel agents in lung cancer in this article. There are many new molecules which are currently being studied for a variety of targets. Histone deacetylase (HDAC) inhibitors and DNA hypomethylating agents target epigenetics for tumor growth suppression. In immunotherapy, new peptide vaccines targeting novel tumor antigens, alternative checkpoint inhibitors, and chimeric antigen receptor $\mathrm{T}$ cells (CAR- $\mathrm{T})$ are being developed for the patients who have failed or intolerant to anti-PD1/anti-PD-L1 therapy. Novel small molecular inhibitors directed to inhibit variety of signaling pathways are being developed to overcome resistance to currently available targeted therapies. Table 1 summarizes currently open phase I/II clinical trials for lung cancer patients with pending results. The information in this table was collected from Clinicaltrils.gov (accessed on September, 2016). It can serve as a guide for clinicians who treat relapsed refractory lung cancer. 
Table 1 Currently open phase I/II clinical trials for lung cancer

\begin{tabular}{|c|c|c|c|c|c|}
\hline Drug class & Drug & Mechanism of action & Clinical trials (phase) & Study design & Disease \\
\hline \multirow[t]{8}{*}{ Tumor epigenetics } & Entinostat & Histone deacetylase (HDAC) inhibitor & NCT02437136 $\underline{(1 / 2)}$ & Combination & NSCLC \\
\hline & HBI-8000 & & NCT02718066 $\underline{(1 / 2)}$ & Combination & NSCLC \\
\hline & ACY 241 & & NCT02635061 (1) & Combination & NSCLC \\
\hline & Epacadostat & & NCT02298153 (1) & Combination & NSCLC \\
\hline & Mocentinostat & & NCT02805660 $\underline{(1 / 2)}$ & Combination & NSCLC \\
\hline & CC-486 & DNA hypomethylation & NCT02250326 (2) & Combination & NSCLC \\
\hline & Azacitidine & & NCT02009436 (1) & Monotherapy & NSCLC \\
\hline & RRX-001 & $\begin{array}{l}\text { DNA methylation, histone deacetylation, } \\
\text { and lysine demethylation }\end{array}$ & NCT02489903 $\underline{(2)}$ & Monotherapy & NSCLC \\
\hline \multirow[t]{6}{*}{ Tumor metabolism } & Ethaselen & Thioredoxin reductase & NCT02166242 (1) & Monotherapy & NSCLC \\
\hline & TAS-114 & dUTPase & NCT02855125 (2) & Combination & NSCLC \\
\hline & ADI-PEG 20 & Pegylated arginine deiminase & NCT02029690 (1) & Combination & NSCLC \\
\hline & ССТ245737 & Checkpoint kinase 1 & NCT02797977 (1) & Combination & NSCLC/SCLC \\
\hline & LY2606368 & & NCT02860780 (1) & Combination & NSCLC/SCLC \\
\hline & CB-839 & Glutaminase & NCT02771626 (1/2) & Combination & NSCLC \\
\hline \multirow[t]{28}{*}{ Immunotherapy } & Cancer vaccines & & & & \\
\hline & CV301 & Tumor peptide vaccine & NCT02840994 (1/2) & Combination & NSCLC \\
\hline & TG4010 & & NCT02823990 (2) & Combination & NSCLC \\
\hline & Gemogenovatucel-T & & NCT02639234 (2) & Combination & NSCLC \\
\hline & CMB305 & & NCT02387125 (1) & Monotherapy & NSCLC \\
\hline & DC-CIK & Dendritic cell vaccine & NCT02688686 (1/2) & Monotherapy & NSCLC \\
\hline & DCVAC/LUCA & & NCT02470468 (1/2) & Monotherapy & NSCLC \\
\hline & AGS-003-LNG & & NCT02662634 (2) & Monotherapy & NSCLC \\
\hline & JNJ-64041757 & Listeria vaccine & NCT02592967 (1) & Monotherapy & NSCLC \\
\hline & ADXS11-001 & & NCT02531854 (2) & Combination & NSCLC \\
\hline & DSP-7888 & WT1 vaccine & NCT02498665 (1) & Monotherapy & NSCLC \\
\hline & S-588410 & (HLA)-a*2402-restricted epitope peptides & NCT02410369 (2) & Monotherapy & NSCLC \\
\hline & AD-MAGEA3 and MG1-MAGEA3 & MAGE-A3-expressing maraba virus & NCT02879760 $\underline{(1 / 2)}$ & Monotherapy & NSCLC \\
\hline & L-DOS47 & Immunoconjugate & NCT02340208 (1/2) & Monotherapy & NSCLC \\
\hline & & & NCT02309892 (1) & Monotherapy & NSCLC \\
\hline & DRibbles & & NCT01909752 (2) & Monotherapy & NSCLC \\
\hline & Checkpoint inhibitors & & & & \\
\hline & Enoblituzumab (MGA271) & B7-H3 antibody & NCT02475213 (1) & Combination & NSCLC \\
\hline & & & NCT01391143 (1) & Monotherapy & NSCLC \\
\hline & MGD009 & & NCT02628535 (1) & Monotherapy & NSCLC \\
\hline & $\mathrm{CM}-24$ & CEACAM1 antibody & NCT02346955 (1) & Combination & NSCLC \\
\hline & Indoximod & $\begin{array}{l}\text { Indoleamine 2,3-dioxygenase } \\
\text { (IDO) inhibitor }\end{array}$ & NCT02460367 (1/2) & Combination & NSCLC \\
\hline & AMG 820 & $\begin{array}{l}\text { Colony-stimulating factor } 1 \\
\text { receptor (CSF1R) }\end{array}$ & NCT02713529 $\underline{(1 / 2)}$ & Combination & NSCLC \\
\hline & PF-05082566 & 4-1BB agonist & NCT02315066 (1) & Combination & NSCLC/SCLC \\
\hline & PBF-509 & Adenosine $\mathrm{A} 2 \mathrm{a}$ & NCT02403193 (1/2) & Combination & NSCLC \\
\hline & CPI-444 & & NCT02655822 (1) & Combination & NSCLC \\
\hline & PF-04518600 & Anti-OX40 mAb & NCT02315066 (1) & Combination & NSCLC/SCLC \\
\hline & JNJ-61610588 & Anti-VISTA & NCT02671955 (1) & Monotherapy & NSCLC/SCLC \\
\hline
\end{tabular}


Table 1 Currently open phase I/II clinical trials for lung cancer (Continued)

\begin{tabular}{|c|c|c|c|c|c|}
\hline & PDR001 & Anti-PD1 & NCT02460224 (1/2) & Combination & NSCLC/SCLC \\
\hline & CA-170 & Oral PDL1/PDL2NISTA inhibitor & NCT02812875 (1) & Monotherapy & NSCLC/SCLC \\
\hline & Avelumab & PD- L1 inhibitor & NCT02584634 (2) & Combination & NSCLC \\
\hline & Varlilumab & Anti-CR27 mAb & NCT02335918 (1) & Combination & NSCLC \\
\hline & JNJ-64457107 & Anti- CD40 & NCT02829099 (1) & Monotherapy & NSCLC/SCLC \\
\hline & Modified T cell therapy & & & & \\
\hline & TIL & Tumor infiltrating lymphocytes & NCT02133196 (2) & Monotherapy & NSCLC \\
\hline & DC-CTL & Combined dendritic cells- & NCT02766348 (2) & Monotherapy & NSCLC \\
\hline & & cytotoxic t lymphocyte & NCT02886897 (1/2) & Combination & NSCLC \\
\hline & IMMUNICELL ${ }^{\oplus}$ & Autologous $\gamma \delta$ - T lymphocytes & NCT02459067 $\underline{(2 / 3)}$ & Monotherapy & NSCLC \\
\hline & MAGE A10 ${ }^{c 796} \mathrm{~T}$ & Chimeric antigen receptor & NCT02592577 (1/2) & Monotherapy & NSCLC \\
\hline & NY-ESO-1 ${ }^{c 259} \mathrm{~T}$ & I lymphocytes & NCT02588612 $\underline{(1 / 2)}$ & Monotherapy & NSCLC \\
\hline & ANTI-MUC1 CAR T & & NCT02587689 (1/2) & Monotherapy & NSCLC \\
\hline & PD1 knockout cells & Modified T cell therapy & NCT02793856 (1) & Monotherapy & NSCLC \\
\hline & Targeted NK cells & Modified NK cell therapy & NCT02118415 (2) & Monotherapy & NSCLC \\
\hline & & & NCT02845856 (1/2) & Combination & NSCLC \\
\hline & WT1-TCRC4-T cells & WT1 targeted t cells & NCT02408016 $\underline{(1 / 2)}$ & Monotherapy & NSCLC \\
\hline & Cytokines & & & & \\
\hline & rSIFN-CO & Recombinant interferon & NCT02387307 (1) & Monotherapy & NSCLC \\
\hline & ALT-803 & IL- 15 agonist & NCT02523469 (1/2) & Combination & NSCLC \\
\hline & AM0010 & Pegylated IL-10 & NCT02009449 (1) & Monotherapy & NSCLC \\
\hline & AAT-007 & Prostaglandin E receptor subtype 4 & NCT02538432 (2) & Monotherapy & NSCLC \\
\hline & Poly-ICL & Toll-like receptor agonist & NCT02661100 (1/2) & Combination & $\mathrm{NSCLC/SCLC}$ \\
\hline & VTX-2337 & & NCT02650635 (1) & Monotherapy & NSCLC \\
\hline & L19-IL2 & Antibody cytokine fusion protein & NCT02735850 (2) & Combination & NSCLC \\
\hline & CDX-1401 & DEC-205/NY-eso-1 fusion protein & NCT02661100 (1/2) & Combination & NSCLC/SCLC \\
\hline Targeted therapy & EGFR inhibitors & & & & \\
\hline & ABBV-221 & EGFR & NCT02365662 (1) & Monotherapy & NSCLC \\
\hline & AC0010MA & EGFR T790M & NCT02448251 $\underline{(1 / 2)}$ & Monotherapy & NSCLC \\
\hline & Tesevatinib & EGFR (CNS penetrant) & NCT02616393 (2) & Monotherapy & NSCLC \\
\hline & JNJ-61186372 & EGFR/MET bispecific mAb & NCT02609776 (1) & Monotherapy & NSCLC \\
\hline & AP32788 & EGFR exon 20 & NCT02716116 (1/2) & Monotherapy & NSCLC \\
\hline & MM-151 and MM-121 & EGFR mAb & NCT02538627 (1) & Monotherapy & NSCLC \\
\hline & TargomiRs & EGFR ab bound mir-16 & NCT02369198 (1) & Monotherapy & NSCLC \\
\hline & Multi-kinase inhibitors & & & & \\
\hline & Navitoclax & Bcl-2, BCl-x, Bcl-w & NCT02520778 (1) & Combination & NSCLC \\
\hline & CT-707 & ALK, FAK, Pyk2 & NCT02695550 (1) & Monotherapy & NSCLC \\
\hline & Famitinib & c-Kit, VEGFR2, PDGFR, VEGFR3, & NCT02356991 (2) & Monotherapy & NSCLC \\
\hline & & FLT1, FLT3 & NCT02364362 (1) & Combination & NSCLC \\
\hline & MGCD516 & $\begin{array}{l}\text { VEGFR, PDGFR, DDR2, TRK } \\
\text { and Eph families }\end{array}$ & NCT02219711 (1) & Monotherapy & $\mathrm{NSCLC/SCLC}$ \\
\hline & Pexidartinib & Kit, FLT3, CAF1r & NCT02452424 (1/2) & Combination & NSCLC \\
\hline & Anlotinib & VEGF1/2/3, FGFR2 & NCT02388919 $\underline{\underline{(2 / 3)}}$ & Monotherapy & NSCLC \\
\hline & Entrectinib & NTRK1/2/3, ROS1, ALK & NCT02568267 (2) & Monotherapy & NSCLC \\
\hline & ASP2215 & Axl, FLT3 & NCT02495233 (1/2) & Combination & NSCLC/SCLC \\
\hline
\end{tabular}


Table 1 Currently open phase I/II clinical trials for lung cancer (Continued)

\begin{tabular}{|c|c|c|c|c|c|}
\hline & \multicolumn{5}{|c|}{ PI3K/mTOR pathway inhibitors } \\
\hline & MLN1117 & $\mathrm{PI} 3 \mathrm{~K}$ & NCT02393209 (1/2) & Combination & NSCLC \\
\hline & AZD8186 & & NCT01884285 $\underline{(1)}$ & Monotherapy & NSCLC \\
\hline & LY3023414 & $\mathrm{PI} 3 \mathrm{~K}, \mathrm{mTOR}$ & NCT02443337 (2) & Combination & NSCLC \\
\hline & \multicolumn{5}{|c|}{ Other miscellaneous target inhibitors } \\
\hline & LEE011 & CDK 4/6 & NCT02292550 $\underline{(1 / 2)}$ & Combination & NSCLC \\
\hline & \multirow[t]{3}{*}{ Abemaciclib } & & NCT02308020 (2) & Monotherapy & NSCLC \\
\hline & & & NCT02779751 (2) & Monotherapy & NSCLC \\
\hline & & & NCT02079636 (1) & Combination & NSCLC \\
\hline & INK128 & TORC1/2 & NCT02503722 $\underline{(1)}$ & Combination & NSCLC \\
\hline & Alisertib & Aurora kinase inhibitor & NCT01471964 $\underline{(1 / 2)}$ & Combination & NSCLC \\
\hline & Ibrutinib & BTK & NCT02321540 $\underline{(1 / 2)}$ & Monotherapy & NSCLC \\
\hline & TAK-659 & Syk & NCT02834247 (1) & Combination & NSCLC \\
\hline & Pyrotinib & HER2 & NCT02535507 (2) & Monotherapy & NSCLC \\
\hline & EphB4-HSA & sEphB4 & NCT02495896 $\underline{(1)}$ & Combination & NSCLC \\
\hline & Ficlatuzumab & Hepatocyte growth factor (HGF) & NCT02318368 (2) & Combination & NSCLC \\
\hline & AMG 479 & IGFR-1 & NCT01061788 (1) & Combination & $\mathrm{NSCLC/SCLC}$ \\
\hline & MM-121 & HER3 & NCT02387216 (2) & Combination & NSCLC \\
\hline & Defactinib & Focal adhesion kinase (FAK) & NCT02758587 (1/2) & Combination & NSCLC \\
\hline & JNJ-42756493 & FGFR & NCT02699606 (2) & Monotherapy & NSCLC \\
\hline & \multicolumn{2}{|l|}{ INCB054828 } & NCT02393248 (1/2) & Monotherapy & $\mathrm{NSCLC/SCLC}$ \\
\hline & LOXO-101 & NTRK1/2/3 & NCT02576431 (2) & Monotherapy & $\mathrm{NSCLC/SCLC}$ \\
\hline & \multicolumn{2}{|l|}{ RXDX-101 } & NCT02097810 (1) & Monotherapy & NSCLC/SCLC \\
\hline & \multicolumn{2}{|l|}{ Rh-endostatin } & NCT02375022 (2) & Combination & NSCLC \\
\hline & \multicolumn{2}{|l|}{ Cediranib } & NCT02498613 (2) & Combination & $\mathrm{NSCLC/SCLC}$ \\
\hline & GSK3052230 & FGF ligand trap & NCT01868022 (1) & Combination & $\mathrm{NSCLC/SCLC}$ \\
\hline & TRC105 & Endoglin (CD105) & NCT02429843 (1) & Combination & NSCLC \\
\hline & MEK162 & MEK & NCT01859026 (1) & Combination & NSCLC \\
\hline & \multicolumn{2}{|l|}{ PD-0325901 } & NCT02022982 (1/2) & Combination & NSCLC \\
\hline & Selumetinib & RAS/RAF/MEK/ERK & NCT01586624 (1) & Combination & NSCLC \\
\hline & Pacritnib & JAK2 & NCT02342353 (1/2) & Monotherapy & NSCLC \\
\hline & AT13387 & Heat shock protein 90 & NCT02535338 $\underline{(1 / 2)}$ & Combination & $\mathrm{NSCLC}$ \\
\hline & \multirow{2}{*}{\multicolumn{2}{|c|}{ AUY922 }} & NCT01922583 (2) & Monotherapy & NSCLC \\
\hline & & & NCT01854034 (2) & Monotherapy & NSCLC \\
\hline & Galunisertib & TGF $\beta$ signaling & NCT02423343(1/2) & Combination & $\mathrm{NSCLC/SCLC}$ \\
\hline & MSC2156119J & MET & NCT01982955 $\underline{(1 / 2)}$ & Combination & NSCLC \\
\hline & Ralimetinib & MAPK & NCT02860780 (1) & Combination & NSCLC/SCLC \\
\hline & \multicolumn{2}{|l|}{ LTT462 } & NCT02711345 (1) & Monotherapy & NSCLC \\
\hline & PF-06671008 & P-cadherin & NCT02659631 (1) & Monotherapy & NSCLC/SCLC \\
\hline & BGB324 & $A \times l$ & NCT02424617 (1/2) & Combination & NSCLC \\
\hline \multirow[t]{3}{*}{ DNA repair } & VX790 & ATR & NCT02487095 (1/2) & Combination & $\mathrm{SCLC}$ \\
\hline & Veliparib & PARP & NCT01386385 (1/2) & Combination & NSCLC \\
\hline & \multicolumn{2}{|l|}{ Olaparib } & NCT02498613 (2) & Combination & NSCLC/SCLC \\
\hline
\end{tabular}


Table 1 Currently open phase I/II clinical trials for lung cancer (Continued)

\begin{tabular}{|c|c|c|c|c|c|}
\hline \multirow[t]{5}{*}{ Chemotherapy } & Plinabulin & Tubulin-depolymerization & NCT02846792 (1/2) & Combination & NSCLC \\
\hline & & & NCT02812667 (1) & Combination & NSCLC \\
\hline & PT-112 & Platinum based & NCT02884479 $\underline{\underline{(1 / 2)}}$ & Combination & $\mathrm{NSCLC} / \mathrm{SCLC}$ \\
\hline & NC-6004 & $\begin{array}{l}\text { Micellar nanoparticle-encapsulated } \\
\text { cisplatin }\end{array}$ & NCT02240238 (1/2) & Combination & NSCLC \\
\hline & EC1456 & Folic acid-tubulysin conjugate & NCT01999738 (1) & Monotherapy & $\mathrm{NSCLC/SCLC}$ \\
\hline \multirow[t]{2}{*}{ Oncolytic virus } & CVA21 & Coxsackievirus A21 & NCT02043665 (1) & Monotherapy & NSCLC \\
\hline & & & NCT02824965 (1) & Combination & NSCLC \\
\hline
\end{tabular}

ALK anaplastic lymphoma kinase, ATR ataxia telangiectasia and Rad3-related protein, $A X L$ AXL receptor tyrosine kinase, BTK Bruton's tyrosine kinase, CDK 4/6 cyclindependent kinase 4/6, CEACAM1 carcinoembryonic antigen-related cell adhesion molecule 1, dUTPase deoxyuridine triphophatase, FAK focal adhesion kinase, FGF fibroblast growth factor, FLT1/3 fms-like tyrosine kinase 1/3, c-Kit proto-oncogene c-Kit, Her2 human epidermal growth factor receptor 2, HLA human leukocyte antigen, IGFR insulin-like growth factor receptor, JAK2 Janus kinase 2, MAGEA3 melanoma-associated antigen 3, MAPK mitogen-activated protein kinase, $M E K$ mitogen-activated protein kinase kinase, $m T O R$ mammalian target of rapamycin, NTRK3 neurotrophic tyrosine kinase, $P A R P$ poly ADP ribose polymerase, PDGFR platelet-derived growth factor receptor, PI3K phosphatidylinositide 3-kinases, sEphB4 soluble extracellular domain of EphB4, Syk spleen tyrosine kinase, VEGFR vascular endothelial growth factor receptor, VISTA V-domain Ig suppressor of T cell activation, WT1 Wilms' tumor protein

\section{Conclusions}

Oncology is changing at a fast pace, and improved outcomes are being observed in most human malignancies. Until now, lung cancer has lagged behind, but novel targeted agents and immunotherapies have shown promising results for this common and aggressive cancer. The rapid development of novel agents targeting those molecular driver alterations in lung cancer will likely further improve the clinical outcomes. The combination of agents that target non-overlap pathways will likely provide additive or synergistic activities. Many studies are ongoing to test new targets for immunotherapy such as inhibitory molecules TIM-3, LAG-3, IDO (Indoleaminepyrrole 2,3-dioxygenase), BTLA (B- and T-lymphocyte attenuator), adenosine, VISTA (V-domain immunoglobulin containing suppressor of $\mathrm{T}$ cell activation), and stimulatory molecules such as 4-1BB, OX40, CD40, and CD27. A great number of clinical studies are underway to test the clinical activities of various immunotherapy combination strategies in different settings. However, there are challenges to conquer. Treatment with target agents inevitably leads to drug resistance. Understanding the resistance mechanisms and developing novel agents or strategies targeting the resistant tumors are largely need. Although immunotherapy has shown durable response in some patients, the majority of patients do not benefit. Immunohistochemistry staining of PD-L1 on tumor cells is extensively studied but still remains as unperfect biomarker. Discovery of new biomarkers or combination of biomarkers are required to guide the selection of patients who most likely benefit from treatment to avoid unnecessary costs and toxicities. Many pre-clinical and clinical studies are ongoing to address these needs.

\section{Abbreviations}

ALK: Anaplastic lymphoma kinase; DCR: Disease control rate; EGFR: Epidermal growth factor receptor; NSCLC: Non-small cell lung cancer; ORR: Overall response rate; PD: Progressive disease; PR: Partial response; SD: Stable disease

\section{Acknowledgements}

None.

Funding

None applicable.

Availability of data and materials

The material supporting the conclusion of this review has been included within the article.

\section{Authors' contributions}

$Y L$ designed the study. BD and $Y L$ drafted the manuscript. WH and AS participated in the manuscript preparation and revisions. BD and $\mathrm{YL}$ designed and finalized the figure. All authors read and approved the final manuscript.

\section{Competing interests}

The authors declare that they have no competing interests.

\section{Consent for publication}

This is not applicable for this review.

Ethics approval and consent to participate

This is not applicable for this review.

Received: 10 September 2016 Accepted: 29 November 2016

Published online: 09 December 2016

\section{References}

1. Goldstraw P, Crowley J, Chansky K, Giroux DJ, Groome PA, Rami-Porta R, Postmus PE, Rusch V, Sobin L, Committee IAftSoLCIS, Institutions P. The IASLC Lung Cancer Staging Project: proposals for the revision of the TNM stage groupings in the forthcoming (seventh) edition of the TNM classification of malignant tumours. J Thorac Oncol. 2007;2(8):706-14.

2. Smith AD, Roda D, Yap TA. Strategies for modern biomarker and drug development in oncology. J Hematol Oncol. 2014;7:70.

3. Zhou C, Wu YL, Chen G, Feng J, Liu XQ, Wang C, Zhang S, Wang J, Zhou S, Ren S, Lu S, Zhang L, Hu C, Luo Y, Chen L, Ye M, Huang J, Zhi X, Zhang Y, Xiu Q, Ma J, You C. Erlotinib versus chemotherapy as first-line treatment for patients with advanced EGFR mutation-positive non-small-cell lung cancer (OPTIMAL, CTONG-0802): a multicentre, open-label, randomised, phase 3 study. Lancet Oncol. 2011;12(8):735-42.

4. Shaw AT, Kim DW, Nakagawa K, Seto T, Crino L, Ahn MJ, De Pas T, Besse B, Solomon BJ, Blackhall F, Wu YL, Thomas M, O'Byrne KJ, Moro-Sibilot D, Camidge DR, Mok T, Hirsh V, Riely GJ, lyer S, Tassell V, Polli A, Wilner KD, Janne PA. Crizotinib versus chemotherapy in advanced ALK-positive lung cancer. N Engl J Med. 2013;368(25):2385-94.

5. Sun W, Yuan X, Tian Y, Wu H, Xu H, Hu G, Wu K. Non-invasive approaches to monitor EGFR-TKI treatment in non-small-cell lung cancer. J Hematol Oncol. 2015;8:95. 
6. Borghaei H, Paz-Ares L, Horn L, Spigel DR, Steins M, Ready NE, Chow LQ, Vokes EE, Felip E, Holgado E, Barlesi F, Kohlhaufl M, Arrieta O, Burgio MA Fayette J, Lena H, Poddubskaya E, Gerber DE, Gettinger SN, Rudin CM, Rizvi N, Crino L, Blumenschein Jr GR, Antonia SJ, Dorange C, Harbison CT, Graf Finckenstein F, Brahmer JR. Nivolumab versus docetaxel in advanced nonsquamous non-small-cell lung cancer. N Engl J Med. 2015;373(17):1627-39.

7. Herbst RS, Baas P, Kim DW, Felip E, Pérez-Gracia JL, Han JY, Molina J, Kim JH, Arvis CD, Ahn MJ, Majem M, Fidler MJ, de Castro G, Garrido M, Lubiniecki GM, Shentu Y, Im E, Dolled-Filhart M, Garon EB. Pembrolizumab versus docetaxel for previously treated, PD-L1-positive, advanced non-small-cell lung cancer (KEYNOTE-010): a randomised controlled trial. Lancet. 2016;387(10027):1540-50

8. Brahmer J, Reckamp KL, Baas P, Crino L, Eberhardt WE, Poddubskaya E, Antonia S, Pluzanski A, Vokes EE, Holgado E, Waterhouse D, Ready N, Gainor J, Aren Frontera O, Havel L, Steins M, Garassino MC, Aerts JG, Domine M, Paz-Ares L, Reck M, Baudelet C, Harbison CT, Lestini B, Spigel DR. Nivolumab versus docetaxel in advanced squamous-cell non-small-cell lung cancer. N Engl J Med. 2015;373(2):123-35.

9. Reck M, Rodriguez-Abreu D, Robinson AG, Hui R, Csoszi T, Fulop A, Gottfried M, Peled N, Tafreshi A, Cuffe S, O'Brien M, Rao S, Hotta K, Leiby MA, Lubiniecki GM, Shentu Y, Rangwala R, Brahmer JR, Investigators K. Pembrolizumab versus chemotherapy for pd-11-positive non-small-cell lung cancer. N Engl J Med. 2016:375:1823-33.

10. Hellmann MD, Gettinger SN, Goldman JW, Brahmer JR, Borghaei H, Chow LQ, Ready N, Gerber DE, Juergens RA, Shepherd FA, Laurie SA, Zhou Y, Geese WJ, Agrawal S, Li X, Antonia SJ. CheckMate 012: safety and efficacy of first-line (1L) nivolumab (nivo; N) and ipilimumab (ipi; I) in advanced (adv) NSCLC. ASCO Meeting Abstracts. 2016;34(15_suppl):3001.

11. Antonia SJ, Lopez-Martin JA, Bendell JC, Ott PA, Taylor MH, Eder JP, Jager D, Le DT, De Braud FG, Morse M, Ascierto PA, Horn L, Amin A, Pillai RN, Evans TR, Harbison CT, Lin C-S, Tschaika M, Calvo E. Checkmate 032: nivolumab (N) alone or in combination with ipilimumab (I) for the treatment of recurrent small cell lung cancer (SCLC). ASCO Meeting Abstracts. 2016;34(15_suppl):100.

12. Rizvi NA, Hellmann MD, Brahmer JR, Juergens RA, Borghaei $H$, Gettinger $S$, Chow LQ, Gerber DE, Laurie SA, Goldman JW, Shepherd FA, Chen AC, Shen Y, Nathan FE, Harbison CT, Antonia S. Nivolumab in combination with platinumbased doublet chemotherapy for first-line treatment of advanced non-smallcell lung cancer. J Clin Oncol. 2016;34(25):2969-79.

13. Lynch TJ, Bell DW, Sordella R, Gurubhagavatula S, Okimoto RA, Brannigan BW, Harris PL, Haserlat SM, Supko JG, Haluska FG, Louis DN, Christiani DC, Settleman J, Haber DA. Activating mutations in the epidermal growth factor receptor underlying responsiveness of non-small-cell lung cancer to gefitinib. N Engl J Med. 2004;350(21):2129-39.

14. Zhong W, Yang X, Yan H, Zhang X, Su J, Chen Z, Liao R, Nie Q, Dong S, Zhou Q, Yang J, Tu H, Wu YL. Phase II study of biomarker-guided neoadjuvant treatment strategy for IIIA-N2 non-small cell lung cancer based on epidermal growth factor receptor mutation status. J Hematol Oncol. 2015:8:54.

15. Zhou C, Wu YL, Chen G, Feng J, Liu XQ, Wang C, Zhang S, Wang J, Zhou S, Ren S, Lu S, Zhang L, Hu C, Luo Y, Chen L, Ye M, Huang J, Zhi X, Zhang Y, Xiu Q, Ma J, You C. Final overall survival results from a randomised, phase III study of erlotinib versus chemotherapy as first-line treatment of EGFR mutation-positive advanced non-small-cell lung cancer (OPTIMAL, CTONG-0802). Ann Oncol. 2015;26(9):1877-83.

16. Maemondo M, Inoue A, Kobayashi K, Sugawara S, Oizumi S, Isobe H, Gemma A, Harada M, Yoshizawa H, Kinoshita I, Fujita Y, Okinaga S, Hirano H, Yoshimori K, Harada T, Ogura T, Ando M, Miyazawa H, Tanaka T, Saijo Y, Hagiwara K, Morita S, Nukiwa T. Gefitinib or chemotherapy for non-smallcell lung cancer with mutated EGFR. N Engl J Med. 2010;362(25):2380-8.

17. Wu YL, Zhou C, Hu CP, Feng J, Lu S, Huang Y, Li W, Hou M, Shi JH, Lee KY, Xu CR, Massey D, Kim M, Shi Y, Geater SL. Afatinib versus cisplatin plus gemcitabine for first-line treatment of Asian patients with advanced nonsmall-cell lung cancer harbouring EGFR mutations (LUX-Lung 6): an openlabel, randomised phase 3 trial. Lancet Oncol. 2014;15(2):213-22.

18. Ramalingam SS, O'Byrne K, Boyer M, Mok T, Janne PA, Zhang H, Liang J, Taylor I, Sbar El, Paz-Ares L. Dacomitinib versus erlotinib in patients with EGFR-mutated advanced nonsmall-cell lung cancer (NSCLC): pooled subset analyses from two randomized trials. Ann Oncol. 2016;27(7):1363.

19. Zhang J, Cao J, Li J, Zhang Y, Chen Z, Peng W, Sun S, Zhao N, Wang J, Zhong D, Zhang X, Zhang J. A phase I study of AST1306, a novel irreversible EGFR and HER2 kinase inhibitor, in patients with advanced solid tumors. J Hematol Oncol. 2014;7:22.
20. Shi Y, Wang L, Han B, Li W, Yu P, Liu Y, Ding C, Song X, Yong MZ, Ren X, Feng JF, Zhang H, Chen G, Wu N, Han X, Yao C, Song Y, Zhang S, Ding L, Tan F. First-line icotinib versus cisplatine/pemetrexed plus pemetrexed maintenance therapy in lung adenocarcinoma patients with sensitizing EGFR mutation (CONVINCE). ASCO Meeting Abstracts. 2016;34(15_suppl):9041.

21. Janne PA, Yang JC, Kim DW, Planchard D, Ohe Y, Ramalingam SS, Ahn MJ, Kim SW, Su WC, Horn L, Haggstrom D, Felip E, Kim JH, Frewer P, Cantarini M, Brown KH, Dickinson PA, Ghiorghiu S, Ranson M. AZD9291 in EGFR inhibitorresistant non-small-cell lung cancer. N Engl J Med. 2015;372(18):1689-99.

22. Sequist LV, Soria JC, Goldman JW, Wakelee HA, Gadgeel SM, Varga A, Papadimitrakopoulou V, Solomon BJ, Oxnard GR, Dziadziuszko R, Aisner DL, Doebele RC, Galasso C, Garon EB, Heist RS, Logan J, Neal JW, Mendenhall MA, Nichols S, Piotrowska Z, Wozniak AJ, Raponi M, Karlovich CA, Jaw-Tsai S, Isaacson J, Despain D, Matheny SL, Rolfe L, Allen AR, Camidge DR. Rociletinib in EGFR-mutated non-small-cell lung cancer. N Engl J Med. 2015;372(18):1700-9.

23. Yu HA, Spira Al, Horn L, Weiss J, West HJ, Giaccone G, Evans TL, Kelly RJ, Desai BB, Krivoshik A, Fleege TE, Poondru S, Jie F, Aoyama K, Whitcomb DA, Keating AT, Oxnard GR. Antitumor activity of ASP8273 $300 \mathrm{mg}$ in subjects with EGFR mutation-positive non-small cell lung cancer: interim results from an ongoing phase 1 study. ASCO Meeting Abstracts. 2016;34(15_suppl):9050.

24. Park K, Lee J-S, Lee KH, Kim J-H, Cho BC, Min YJ, Cho JY, Han J-Y, Kim B-S, Kim J-S, Lee DH, Kang JH, Cho EK, Kim H-G, Lee KH, Kim HK, Jang I-J, Kim HY, Son J, Kim D-W. BI 1482694 (HM61713), an EGFR mutant-specific inhibitor, in T790M+ NSCLC: efficacy and safety at the RP2D. ASCO Meeting Abstracts. 2016;34(15_suppl):9055.

25. Tan DS-W, Yang JC-H, Leighl NB, Riely GJ, Sequist LV, Felip E, Seto T, Wolf J, Moody SE, Adams K, Schmitz S-FH, Tan EY, Kim D-W. Updated results of a phase 1 study of EGF816, a third-generation, mutant-selective EGFR tyrosine kinase inhibitor (TKI), in advanced non-small cell lung cancer (NSCLC) harboring T790M. ASCO Meeting Abstracts. 2016;34(15 suppl):9044.

26. Ahn M-J, Kim D-W, Kim TM, Lin C-C, Ratnayake J, Carlie DJ, Yin X, Yang Z, Jiang H, Yang JC-H. Phase I study of AZD3759, a CNS penetrable EGFR inhibitor, for the treatment of non-small-cell lung cancer (NSCLC) with brain metastasis (BM) and leptomeningeal metastasis (LM). ASCO Meeting Abstracts. 2016;34(15_suppl):9003.

27. Yang JC-H, Kim D-W, Kim S-W, Cho BC, Lee J-S, Ye X, Yin X, Yang Z, Jiang H, Ahn M-J. Osimertinib activity in patients (pts) with leptomeningeal (LM) disease from non-small cell lung cancer (NSCLC): updated results from BLOOM, a phase I study. ASCO Meeting Abstracts. 2016;34(15_suppl):9002.

28. Zhou Q, Gan B, Yuan L, Hua Y, Wu Y-L. The safety profile of a selective EGFR TKI epitinib (HMPL-813) in patients with advanced solid tumors and preliminary clinical efficacy in EGFRm+ NSCLC patients with brain metastasis. ASCO Meeting Abstracts. 2016;34(15_suppl):e20502.

29. Shaw AT, Yeap BY, Mino-Kenudson M, Digumarthy SR, Costa DB, Heist RS, Solomon B, Stubbs H, Admane S, McDermott U, Settleman J, Kobayashi S, Mark EJ, Rodig SJ, Chirieac LR, Kwak EL, Lynch TJ, lafrate AJ. Clinical features and outcome of patients with non-small-cell lung cancer who harbor EML4-ALK. J Clin Oncol. 2009;27(26):4247-53.

30. Kim DW, Mehra R, Tan DS, Felip E, Chow LQ, Camidge DR, Vansteenkiste J, Sharma S, De Pas T, Riely GJ, Solomon BJ, Wolf J, Thomas M, Schuler M, Liu G, Santoro A, Sutradhar S, Li S, Szczudlo T, Yovine A, Shaw AT. Activity and safety of ceritinib in patients with ALK-rearranged non-small-cell lung cancer (ASCEND-1): updated results from the multicentre, open-label, phase 1 trial. Lancet Oncol. 2016;17(4):452-63.

31. Ou SH, Ahn JS, De Petris L, Govindan R, Yang JC, Hughes B, Lena H, MoroSibilot D, Bearz A, Ramirez SV, Mekhail T, Spira A, Bordogna W, Balas B, Morcos PN, Monnet A, Zeaiter A, Kim DW. Alectinib in crizotinib-refractory ALK-rearranged non-small-cell lung cancer: a phase II global study. J Clin Oncol. 2016;34(7):661-8.

32. Iragavarapu C, Mustafa M, Akinleye A, Furqan M, Mittal V, Cang S, Liu D. Novel ALK inhibitors in clinical use and development. J Hematol Oncol. 2015;8:17.

33. Kim D-W, Tiseo M, Ahn M-J, Reckamp KL, Holmskov Hansen K, Kim S-W, Huber RM, West HJ, Groen HJM, Hochmair MJ, Leighl NB, Gettinger SN, Langer CJ, Paz-Ares LG, Smit EF, Kim ES, Reichmann WG, Kerstein D, Haluska FG, Camidge DR. Brigatinib (BRG) in patients (pts) with crizotinib (CRZ)-refractory ALK+ non-small cell lung cancer (NSCLC): first report of efficacy and safety from a pivotal randomized phase (ph) 2 trial (ALTA). ASCO Meeting Abstracts. 2016;34(15_suppl):9007. 
34. Solomon BJ, Bauer TM, Felip E, Besse B, James LP, Clancy JS, Klamerus KJ, Martini J-F, Abbattista A, Shaw AT. Safety and efficacy of lorlatinib (PF06463922) from the dose-escalation component of a study in patients with advanced ALK+ or ROS1+ non-small cell lung cancer (NSCLC). ASCO Meeting Abstracts. 2016;34(15_suppl):9009.

35. Zou HY, Friboulet L, Kodack DP, Engstrom LD, Li Q, West M, Tang RW, Wang $H_{\text {, }}$ Tsaparikos K, Wang J, Timofeevski S, Katayama R, Dinh DM, Lam H, Lam JL, Yamazaki S, Hu W, Patel B, Bezwada D, Frias RL, Lifshits E, Mahmood S, Gainor JF, Affolter T, Lappin PB, Gukasyan H, Lee N, Deng S, Jain RK, Johnson TW, et al. PF-06463922, an ALK/ROS1 inhibitor, overcomes resistance to first and second generation alk inhibitors in preclinical models. Cancer Cell. 2015;28(1):70-81.

36. Horn L, Wakelee HA, Reckamp KL, Blumenschein GR, Infante JR, Carter CA, Waqar SN, Neal JW, Gockerman JP, Harrow K, Dukart G, Liang C, Gibbons JJ, Hernandez J, Newman-Eerkes T, Lim L, Lovly CM. Plasma genotyping of patients enrolled on the expansion phase I/II trial of X-396 in patients (pts) with ALK+ non-small cell lung cancer (NSCLC). ASCO Meeting Abstracts. 2016;34(15_suppl):9056.

37. Shi P, Oh YT, Zhang G, Yao W, Yue P, Li Y, Kanteti R, Riehm J, Salgia R, Owonikoko TK, Ramalingam SS, Chen M, Sun SY. Met gene amplification and protein hyperactivation is a mechanism of resistance to both first and third generation EGFR inhibitors in lung cancer treatment. Cancer Lett. 2016:380(2):494-504.

38. Awad MM, Oxnard GR, Jackman DM, Savukoski DO, Hall D, Shivdasani P, Heng JC, Dahlberg SE, Janne PA, Verma S, Christensen J, Hammerman PS, Sholl LM. MET exon 14 mutations in non-small-cell lung cancer are associated with advanced age and stage-dependent met genomic amplification and c-Met overexpression. J Clin Oncol. 2016;34(7):721-30.

39. Camidge DR, Ou S-HI, Shapiro G, Otterson GA, Villaruz LC, Villalona-Calero MA, lafrate AJ, Varella-Garcia M, Dacic S, Cardarella S, Zhao W, Tye L, Stephenson P, Wilner KD, James LP, Socinski MA. Efficacy and safety of crizotinib in patients with advanced c-MET-amplified non-small cell lung cancer (NSCLC). ASCO Meeting Abstracts. 2014;32(15_suppl):8001.

40. Paik PK, Drilon A, Fan PD, Yu H, Rekhtman N, Ginsberg MS, Borsu L, Schultz N, Berger MF, Rudin CM, Ladanyi M. Response to MET inhibitors in patients with stage IV lung adenocarcinomas harboring MET mutations causing exon 14 skipping. Cancer Discov. 2015;5(8):842-9.

41. Schuler MH, Berardi R, Lim W-T, Geel RV, De Jonge MJ, Bauer TM, Azaro A, Gottfried M, Han J-Y, Lee DH, Wollner M, Hong DS, Vogel A, Delmonte A, Krohn A, Zhang Y, Squires M, Giovannini M, Akimov M, Bang Y-J. Phase (Ph) I study of the safety and efficacy of the CMET inhibitor capmatinib (INC280) in patients (pts) with advanced cMET+ non-small cell lung cancer (NSCLC). ASCO Meeting Abstracts. 2016;34(15_suppl):9067

42. Wu Y-L, Kim D-W, Felip E, Zhang L, Liu X, Zhou CC, Lee DH, Han J-Y, Krohn A, Lebouteiller R, Xu C, Squires M, Akimov M, Tan DS-W. Phase (Ph) II safety and efficacy results of a single-arm ph ib/ll study of capmatinib (INC280) + gefitinib in patients (pts) with EGFR-mutated (mut), cMET-positive (cMET+) non-small cell lung cancer (NSCLC). ASCO Meeting Abstracts. 2016;34(15_suppl):9020.

43. Wu Y-L, Soo RA, Kim D-W, Yang JC-H, Stammberger UM, Chen W, Johne A, Park K. Tolerability, efficacy and recommended phase II dose (RP2D) of tepotinib plus gefitinib in Asian patients with c-Met-positive/EGFR-mutant NSCLC: Phase Ib data. ASCO Meeting Abstracts. 2016;34(15_suppl):e20501.

44. Camidge DR, Moran T, Demedts I, Grosch H, Di Mercurio J-P, Mileham KF, Molina JR, Juan Vidal O, Bepler G, Goldman JW, Lewanski C, Park K, Wallin J, Wijayawardana SR, Wang XA, Wacheck V, Smit EF. A randomized, open-label, phase 2 study of emibetuzumab plus erlotinib $(L Y+E)$ and emibetuzumab monotherapy $(L Y)$ in patients with acquired resistance to erlotinib and MET diagnostic positive (MET Dx+) metastatic NSCLC. ASCO Meeting Abstracts. 2016;34(15_suppl):9070.

45. Drilon AE, Sima CS, Somwar R, Smith R, Ginsberg MS, Riely GJ, Rudin CM, Ladanyi M, Kris MG, Rizvi NA. Phase II study of cabozantinib for patients with advanced RET-rearranged lung cancers. ASCO Meeting Abstracts. 2015:33(15 suppl):8007.

46. Seto T, Yoh K, Satouchi M, Nishio M, Yamamoto N, Murakami H, Nogami N, Nosaki K, Urata Y, Niho S, Horiike A, Kohno T, Matsumoto S, Nomura S, Kuroda S, Sato A, Ohe Y, Yamanaka T, Ohtsu A, Goto K. A phase II openlabel single-arm study of vandetanib in patients with advanced RETrearranged non-small cell lung cancer (NSCLC): Luret study. ASCO Meeting Abstracts. 2016;34(15_suppl):9012.

47. Cascone T, Subbiah V, Hess KR, Nelson S, Nilsson MB, Subbiah IM, Ali SM, Carbone DP, Salgia R, Owonikoko TK, Meric-Bernstam F, Doebele RC, Heymach J, *Vivek Subbiah and Tina Cascone Equally contributed to t.
Significant systemic and CNS activity of RET inhibitor vandetanib combined with mTOR inhibitor everolimus in patients with advanced NSCLC with RET fusion. ASCO Meeting Abstracts. 2016;34(15_suppl):9069

48. Villaruz LC, Socinski MA, Abberbock S, Berry LD, Johnson BE, Kwiatkowski DJ, lafrate AJ, Varella-Garcia M, Franklin WA, Camidge DR, Sequist LV, Haura EB, Ladanyi M, Kurland BF, Kugler K, Minna JD, Bunn PA, Kris MG. Clinicopathologic features and outcomes of patients with lung adenocarcinomas harboring BRAF mutations in the Lung Cancer Mutation Consortium. Cancer. 2015; 121(3):448-56.

49. Planchard D, Kim TM, Mazieres J, Quoix E, Riely G, Barlesi F, Souquet PJ, Smit EF, Groen HJ, Kelly RJ, Cho BC, Socinski MA, Pandite L, Nase C, Ma B, D'Amelio Jr A, Mookerjee B, Curtis Jr CM, Johnson BE. Dabrafenib in patients with BRAF(V600E)-positive advanced non-small-cell lung cancer: a single-arm, multicentre, open-label, phase 2 trial. Lancet Oncol. 2016;17(5):642-50.

50. Planchard D, Besse B, Groen HJ, Souquet PJ, Quoix E, Baik CS, Barlesi F, Kim TM, Mazieres J, Novello S, Rigas JR, Upalawanna A, D'Amelio Jr AM, Zhang P, Mookerjee $B$, Johnson BE. Dabrafenib plus trametinib in patients with previously treated BRAF(V600E)-mutant metastatic non-small cell lung cancer: an openlabel, multicentre phase 2 trial. Lancet Oncol. 2016;17(7):984-93.

51. Ebert PJ, Cheung J, Yang Y, McNamara E, Hong R, Moskalenko M, Gould SE, Maecker H, Irving BA, Kim JM, Belvin M, Mellman I. MAP kinase inhibition promotes T cell and anti-tumor activity in combination with PD-L1 checkpoint blockade. Immunity. 2016:44(3):609-21.

52. Bendell JC, Kim TW, Goh BC, Wallin J, Oh D-Y, Han S-W, Lee CB, Hellmann MD, Desai J, Lewin JH, Solomon BJ, Chow LQM, Miller WH, Gainor JF, Flaherty K, Infante JR, Das-Thakur M, Foster P, Cha E, Bang Y-J. Clinical activity and safety of cobimetinib (cobi) and atezolizumab in colorectal cancer (CRC). ASCO Meeting Abstracts. 2016;34(15_suppl):3502.

53. Sequist LV, Heist RS, Shaw AT, Fidias P, Rosovsky R, Temel JS, Lennes IT, Digumarthy S, Waltman BA, Bast E, Tammireddy S, Morrissey L, Muzikansky A, Goldberg SB, Gainor J, Channick CL, Wain JC, Gaissert H, Donahue DM, Muniappan A, Wright C, Willers H, Mathisen DJ, Choi NC, Baselga J, Lynch TJ, Ellisen LW, Mino-Kenudson M, Lanuti M, Borger DR, et al. Implementing multiplexed genotyping of non-small-cell lung cancers into routine clinical practice. Ann Oncol. 2011;22(12):2616-24.

54. Cancer Genome Atlas Research N. Comprehensive genomic characterization of squamous cell lung cancers. Nature. 2012;489(7417):519-25.

55. Machacek M, Renaud L, Dimitrijevic S, Schmitz D, Ivanova E, Jorga K. Population pharmacokinetics of PQR309, a dual PI3K/mTOR inhibitor in adult patients with advanced solid tumors. ASCO Meeting Abstracts. 2016:34(15_suppl):e14101.

56. Yonesaka K, Hirotani K, Von Pawel J, Dediu M, Chen S, Copigneaux C, Nakagawa K. Soluble heregulin, HER3 ligand, to predict the efficacy of antiHER3 antibody patritumab combination with erlotinib in randomized phase II study, HERALD, for non-small cell lung cancer. ASCO Meeting Abstracts. 2016;34(15_suppl):9071.

57. Godwin JL, Mehra R, Litwin S, Olszanski AJ, Bauman JR, Borghaei H. A phase I/II study of MLN-8237 (alisertib), an oral aurora kinase inhibitor, in combination with erlotinib in patients with recurrent or metastatic EGFR wild-type nonsmall cell lung cancer. ASCO Meeting Abstracts. 2016;34(15_suppl):e20588.

58. Sousa V, Reis D, Silva M, Alarcao AM, Ladeirinha AF, d'Aguiar MJ, Ferreira T, Caramujo-Balseiro S, Carvalho L. Amplification of FGFR1 gene and expression of FGFR1 protein is found in different histological types of lung carcinoma. Virchows Arch. 2016:469(2):173-82.

59. Nogova L, Sequist LV, Cassier PA, Hidalgo M, Delord J-P, Schuler MH, Lim WT, Camidge DR, Buettner R, Heukamp LC, Gardizi M, Scheffler M, Kambartel K, Ringeisen FP, Sen S, Isaacs R, Joannaert M, Lefebvre C, Wolf J. Targeting FGFR1-amplified lung squamous cell carcinoma with the selective pan-FGFR inhibitor BGJ398. ASCO Meeting Abstracts. 2014;32(15_suppl):8034.

60. Lim SH, Sun J-M, Choi Y-L, Kim HR, Ahn S, Lee JY, Lee S-H, Ahn JS, Park K, Kim JH, Cho BC, Ahn M-J. Efficacy and safety of dovitinib in pretreated patients with advanced squamous non-small cell lung cancer with FGFR1 amplification: a single-arm, phase 2 study. Cancer 2016. DOI: 10.1002/cncr.30135.

61. Dai CH, Chen P, Li J, Lan T, Chen YC, Qian H, Chen K, Li MY. Co-inhibition of pol theta and HR genes efficiently synergize with cisplatin to suppress cisplatin-resistant lung cancer cells survival. Oncotarget. 2016. doi:10.18632/ oncotarget.11214. [Epub ahead of print].

62. Ramalingam SS, Blais N, Mazieres J, Reck M, Jones CM, Juhasz E, Urban L, Orlov S, Barlesi F, Kio E, Keiholz U, Qin Q, Qian J, Nickner C, Dziubinski J, Xiong H, Ansell P, McKee MD, Giranda V Gorbunova V Randomized, placebo-controlled, phase 2 study of veliparib in combination with carboplatin and paclitaxel for advanced/ 
metastatic non-small cell lung cancer. Clin Cancer Res. 2016. doi:10.1158/10780432.CCR-15-3069. [Epub ahead of print].

63. Alexandrov LB, Nik-Zainal S, Wedge DC, Aparicio SA, Behjati S, Biankin AV, Bignell GR, Bolli N, Borg A, Borresen-Dale AL, Boyault S, Burkhardt B, Butler AP, Caldas C, Davies HR, Desmedt C, Eils R, Eyfjord JE, Foekens JA, Greaves M, Hosoda F, Hutter B, llicic T, Imbeaud S, Imielinski M, Jager N, Jones DT, Jones D, Knappskog S, Kool M, et al. Signatures of mutational processes in human cancer. Nature. 2013:500(7463):415-21.

64. Barlesi F, Park K, Ciardiello F, von Pawel J, Gadgeel S, Hida T, Kowalski D, Dols MC, Cortinovis D, Leach J, Polikoff J, Gandara D, Barrios CH, Chen DS, He P, Kowanetz M, Ballinger M, Waterkamp D, Sandler A, Rittmeyer A. Primary analysis from OAK, a randomized phase III study comparing atezolizumab with docetaxel in 2L/3L NSCLC. Ann Oncol. 2016;27 suppl 6:LBA44 PR.

65. Antonia S, Goldberg SB, Balmanoukian A, Chaft JE, Sanborn RE, Gupta A, Narwal R, Steele K, Gu Y, Karakunnel JJ, Rizvi NA. Safety and antitumour activity of durvalumab plus tremelimumab in non-small cell lung cancer: a multicentre, phase 1b study. Lancet Oncol. 2016;17(3):299-308.

66. Tan WL, Jain A, Takano A, Newell EW, lyer NG, Lim WT, Tan EH, Zhai W, Hillmer AM, Tam WL, Tan DS. Novel therapeutic targets on the horizon for lung cancer. Lancet Oncol. 2016;17(8):e347-62.

67. Voo KS, Bover L, Harline ML, Vien LT, Facchinetti V, Arima K, Kwak LW, Liu YJ. Antibodies targeting human OX40 expand effector $T$ cells and block inducible and natural regulatory T cell function. J Immunol. 2013;191(7):3641-50.

68. Toniatti C, Yanamandra N, Voo K, Al-Shami A, Bover L, Morley P, Brett S, Lofton T, Greer J, Feng N, Wistuba II, Bhattacharya S, Hopson C, Kilian D, Jackson H, Bojczuk P, Mandal M, Jing J, French K, Srinivasan R, Hoos A: Abstract 4864: Engaging the immune system with GSK3174998, a potent anti-OX40 agonist antibody. Cancer Res. 2016;76 Suppl 14:4864. doi:10. 1158/1538-7445.AM2016-4864

69. Guo Z, Wang X, Cheng D, Xia Z, Luan M, Zhang S. PD-1 blockade and OX40 triggering synergistically protects against tumor growth in a murine model of ovarian cancer. PLoS One. 2014;9(2):e89350. doi:10.1371/journal.pone.0089350.

70. Nguyen LT, Ohashi PS. Clinical blockade of PD1 and LAG3 - potential mechanisms of action. Nat Rev Immunol. 2015;15(1):45-56.

71. Koyama S, Akbay EA, Li YY, Herter-Sprie GS, Buczkowski KA, Richards WG, Gandhi L, Redig AJ, Rodig SJ, Asahina H, Jones RE, Kulkarni MM, Kuraguchi M, Palakurthi S, Fecci PE, Johnson BE, Janne PA, Engelman JA, Gangadharan SP, Costa DB, Freeman GJ, Bueno R, Hodi FS, Dranoff G, Wong KK, Hammerman PS. Adaptive resistance to therapeutic PD-1 blockade is associated with upregulation of alternative immune checkpoints. Nat Commun. 2016;7:10501.

72. Tolcher AW, Alley EW, Chichili G, Baughman JE, Moore PA, Bonvini E, Vasselli JR, Wigginton JM, Powderly JD. Phase 1, first-in-human, open label, dose escalation ctudy of MGD009, a humanized B7-H3 x CD3 dualaffinity re-targeting (DART) protein in patients with B7-H3-expressing neoplasms or B7-H3 expressing tumor vasculature. ASCO Meeting Abstracts. 2016;34(15_suppl):TPS3105.

73. Quoix E, Lena H, Losonczy G, Forget F, Chouaid C, Papai Z, Gervais R, Ottensmeier C, Szczesna A, Kazarnowicz A, Beck JT, Westeel V, Felip E, Debieuvre D, Madroszyk A, Adam J, Lacoste G, Tavernaro A, Bastien B, Halluard C, Palanche T, Limacher JM. TG4010 immunotherapy and firstline chemotherapy for advanced non-small-cell lung cancer (TIME): results from the phase $2 \mathrm{~b}$ part of a randomised, double-blind, placebocontrolled, phase 2b/3 trial. Lancet Oncol. 2016;17(2):212-23.

74. Gray JE, Chiappori A, Williams CC, Tanvetyanon T, Haura EB, Creelan BC, Devane RD, Smilee R, Noyes D, Kim J, Antonia SJ. Phase I/I randomized trial of GM.CD40L vaccine plus/minus CCL21 in advanced lung adenocarcinoma: final results. ASCO Meeting Abstracts. 2016;34(15_suppl):9037.

75. Camidge DR, Heist RS, Masters GA, Scheff RJ, Starodub A, Messersmith WA Bardia A, Ocean AJ, Horn L, Berlin J, Maliakal PP, Sharkey RM, Wilhelm F, Goldenberg DM, Guarino MJ. Therapy of metastatic, non-small cell lung cancer (mNSCLC) with the anti-Trop-2-SN-38 antibody-drug conjugate (ADC), sacituzumab govitecan (IMMU-132). ASCO Meeting Abstracts. 2016;34(15_suppl):9011.

76. Starodub A, Camidge DR, Scheff RJ, Thomas SS, Guarino MJ, Masters GA Kalinsky K, Gandhi L, Bardia A, Messersmith WA, Ocean AJ, Maliakal PP, Sharkey RM, Wilhelm F, Goldenberg DM, Heist RS. Trop-2 as a therapeutic target for the antibody-drug conjugate (ADC), sacituzumab govitecan (IMMU-132), in patients (pts) with previously treated metastatic small-cell lung cancer (mSCLC). ASCO Meeting Abstracts. 2016;34(15_suppl):8559.

77. Rudin CM, Pietanza MC, Bauer TM, Spigel DR, Ready N, Morgensztern D, Glisson BS, Byers LA, Johnson ML, Burris HA, Robert F, Strickland DK, Zayed H,
Govindan R, Dylla S, Peng SL. Safety and efficacy of single-agent rovalpituzumab tesirine (SC16LD6.5), a delta-like protein 3 (DLL3)-targeted antibody-drug conjugate (ADC) in recurrent or refractory small cell lung cancer (SCLC). ASCO Meeting Abstracts. 2016;34(15_suppl):LBA8505.

78. Becerra C, Spira Al, Conkling PR, Richey SL, Hanna WT, Cote GM, Heist RS, Langleben A, Laurie SA, Edenfield WJ, Kossler K, Hume S, Li Y, Hitron M, Li C. A phase Ib/II study of cancer stemness inhibitor napabucasin (BB608) combined with weekly paclitaxel in advanced non-small cell lung cancer. ASCO Meeting Abstracts. 2016;34(15_suppl):9093.

79. McKeage MJ, Hughes BGM, Markman B, Hidalgo M, Millward M, Jameson MB, Harris DL, Stagg RJ, Kapoun AM, Holmgren E, Dupont J, Kotasek D. A phase 1b study of the anti-cancer stem cell agent demcizumab (DEM), pemetrexed (PEM) \& carboplatin (CARBO) in patients (pts) with 1st line non-squamous NSCLC. ASCO Meeting Abstracts. 2016;34(15_suppl):9023.

80. Chiang AC, Rudin CM, Spira Al, Jotte RM, Gadgeel SM, Mita AC, Hart LL, Gluck WL, Liu SV, Kapoun AM, Xu L, Hill D, Zhou L, Dupont J, Spigel DR. Updated results of phase $1 \mathrm{~b}$ study of tarextumab (TRXT, anti-Notch2/3) in combination with etoposide and platinum (EP) in patients (pts) with untreated extensive-stage small-cell lung cancer (ED-SCLC). ASCO Meeting Abstracts. 2016;34(15_suppl):8564.

\section{Submit your next manuscript to BioMed Central and we will help you at every step:}

- We accept pre-submission inquiries

- Our selector tool helps you to find the most relevant journal

- We provide round the clock customer support

- Convenient online submission

- Thorough peer review

- Inclusion in PubMed and all major indexing services

- Maximum visibility for your research

Submit your manuscript at www.biomedcentral.com/submit
( Biomed Central 